\title{
The effects of the increased doses of leonardite applications on the content of some macro and micro nutrient elements of pak choi (Brassica rapa L. subsp. var. Chinensis L.) plant
}

\author{
Aydin Adiloglu ${ }^{1}$, Funda Eryilmaz Acikgoz ${ }^{2}$, Yusuf Solmaz ${ }^{1 *}$, Sevinc Adiloglu ${ }^{1}$, M. Rustu \\ Karaman $^{3}$ \\ ${ }^{I}$ Namik Kemal University, Agricultural Faculty, Soil Science and Plant Nutrition Department, Tekirdag, Turkey \\ ${ }^{2}$ Namik Kemal University, Vocational Collage of Technical Science, Department of Plant and Animal \\ Production, Tekirdag, Turkey \\ ${ }^{3}$ Afyon Kocatepe University, Vocational Collage of Sultandagi, Department of Medical and Aromatic Plants, \\ Afyonkarahisar, Turkey
}

*Corresponding author e-mail: ysfsolmaz@gmail.com

\begin{abstract}
The present research has been contented to determine the effects of the increased leonardite application on the some macro and micro nutrient elements of pak choi (Brassica rapa L. subsp. var. Chinensis L.) plant. The research was designed as 3 replications according to the randomized block experimental design. Leonardite was applied to the parcels with 4 doses and as the $1^{\text {st }}$ dose: $0 \mathrm{ppm} \mathrm{m}^{-2}$, the $2^{\text {nd }}$ dose: $60 \mathrm{ppm} \mathrm{m}^{-2}$, the $3^{\text {rd }}$ dose: $120 \mathrm{ppm} \mathrm{m}^{-2}$ and the $4^{\text {th }}$ dose: $150 \mathrm{ppm} \mathrm{m}^{-2}$. According to research results, the total $\mathrm{N}$ content of the plant samples were determined of $5.43 \%, 5.58 \%, 5.69 \%$, and $5.73 \%$ for four leonardite doses respectively. The contents were determined as P $(0.40 \%, 0.42 \%, 0.41 \%, 0.41 \%) ; \mathrm{K}(5.49 \%, 5.73 \%, 5.83 \%, 6.01 \%) ; \mathrm{Ca}(1.85 \%, 1.91 \%, 2.06 \%, 2.29 \%) ; \mathrm{Mg}$ $(0.12 \%, 0.13 \%, 0.13 \%, 0.14 \%)$; and S $(3.39 \%, 4.65 \%, 4.83 \%, 4.84 \%)$ and some micro elements contents were obtained as Fe $\left(96,110,112,120 \mathrm{mgkg}^{-1}\right) ; \mathrm{Cu}\left(5,8,18,24 \mathrm{mgkg}^{-1}\right) ; \mathrm{Mn}\left(12,16,22,94 \mathrm{mgkg}^{-1}\right)$; and $\mathrm{Zn}(32$, $34,36,37 \mathrm{mgkg}^{-1}$ ) for four doses, respectively. According to the results, the effects of the increasing doses of the leonardite application on some macro and micro nutrient elements contents of pak choi plant were determined statistically significant. These increases were found to be significant at the level of $5 \%$ statistical degree, except $\mathrm{P}$ and $\mathrm{Mg}$ nutrient elements.
\end{abstract}

Key words: Leonardite, nutrient element, Brassica rapa L. subsp. var. Chinensis L., exotic vegetable.

\section{Introduction}

The cabbage-kind vegetables are known and consumed almost in every part of the world (Tirasoglu et al., 2005). The pak choi is such as vegetable which belongs to this family.

Pak choi (syn. Brassica Chinensis L. (1759), Brassica Campestris L. subsp. Chinensis (L.) Makino, 1912, Brassica rapa L. subsp. Chinensis (L.) Hanelt, 1986) is a vegetable, known since the $5^{\text {th }}$ A. D., which is widely seen China and Taiwan. It is classified in the group which is known as Chinese vegetables (Dixon, 2007; Eryilmaz Acikgoz, 2016). Its leaves are edible and it needs some 50-60 days for vegetation (Opena et al. 1988; Larkcom, 2007). 
The most common waste material in our country is vegetable fertilizers which are not used as compost and leonardite because of wrong procedure of usage, which in addition to the above the usage in the current wrong form, has lots of environmental side effects (Bellitürk, 2016). The Leonardite may have effects on the plant improvement (Chen and Aviad, 1990). According to Tan (2003) these effects include development of the soil properties such as aggregation, aeration, permeability, water holding capacity, micronutrient transport and availability.

Another effects are those, which suppose uptake of humic matters into the plant tissue out coming in diverse biochemical effects (Chen and Aviad, 1990; Nardi, et al.,2002; Escobar, et al., 1996). According to Ece et al., (2007) extreme apply of chemical fertilizers can be induce environmental pollution. For this reason, native alternates to chemical fertilizers are increasing in agricultural output.

According to Akinremi et al., (2000) leonardite is abundant in organic substance (50-75\%) and its humic acid content could change between 30-80\%. According to Chen and Aviad, 1990 effects of humic acid including fertilizers on plant yield and nutrient uptake depend on humic acid source, concentration, application type, plant species and cultivars. According to Akinremi et al., 2000; Dursun et al., 2002; Serenella et al., 2002; Cimrin and Yilmaz, 2005; Unlu et al., 2010 humic compounds rise plant nutrients and intake of nutrient from soil. This research was done to state the effects of the increasing doses of the leonardite application on some macro and micro mineral material content of pak choi.

\section{Materials and Methods}

The high tunnel unheated greenhouse covered by polyetilen (PE) with UV additive of Namik Kemal University, Vocational College of Technical Sciences, Plant and Animal Production Department was used for the experiments which were carried out in late autumn, Tekirdag city (Turkey) (40 $98^{\prime} \mathrm{N}, 27^{\circ} 48^{\prime}$ E) in 2014.

The $134^{\circ} \mathrm{C}$ variety of pak choi (Chiltern Seeds Firm) was used for the research. Seeds were sown in multicelled trays filled with peat (Klasmann-Deilmann, PotgroundH, Germany). Some properties of the used peat are as follow: 160-260 mg/L N, 180-280 mg/L $\mathrm{P}_{2} \mathrm{O}_{5}, 200-150 \mathrm{mg} / \mathrm{L} \mathrm{K} \mathrm{K}_{2} \mathrm{O}, 80-150 \mathrm{mg} / \mathrm{L} \mathrm{Mg}$, pH: $6,70 \%$ organic matter, and $35 \% \mathrm{C}$.

When the seedlings became 2 to 3 true leaves (21days for pak choi after seed sowing) they were planted to pre-prepared places in the high tunnel cold greenhouse with $10 \times 10 \mathrm{~cm}$ intervals and 10 plants in each parcel (Figure 1).

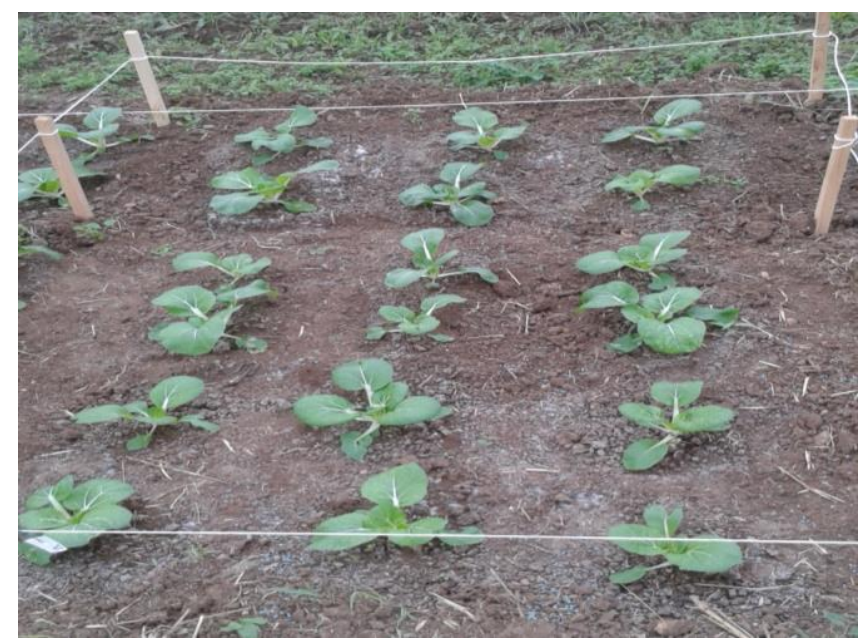

Figure 1. A general view of research (Original, 2014). 
The research was designed according to the randomized block design as 3 replications. The leonardite was applied to the parcels with 4 doses. These doses are the $1^{\text {st }}$ dose: $0 \mathrm{ppm} \mathrm{m}^{-2}$, the $2^{\text {nd }}$ dose: $60 \mathrm{ppm} \mathrm{m}^{-2}$, the $3^{\text {rd }}$ dose: $120 \mathrm{ppm} \mathrm{m}^{-2}$, and the $4^{\text {th }}$ dose: $150 \mathrm{ppm} \mathrm{m}^{-2}$. According to the soil analysis results, $\mathrm{NH}_{4} \mathrm{NO}_{3}$ and $\mathrm{KH}_{2} \mathrm{PO}_{4}$ fertilizers were applied for each parcel.

The plants were harvested 50 days after the seed sowing. Some chemical properties of the commercial leonardite that was purchased in Turkey and research area soil can be seen in the Table 1 and Table 2, and some climate data in cold greenhouse are given in the Table 3 below.

Table 1. Some chemical characteristics of leonardite, (W/W)

\begin{tabular}{llll}
\hline $\mathrm{pH}$ & Organic matter, $\%$ & Moisture, $\%$ & Total humic+fulvic acide, $\%$ \\
\hline 5.2 & 60.6 & 42.9 & 59.1 \\
\hline
\end{tabular}

Table 2. Some chemical and physical characteristics of research area soil.

\begin{tabular}{ll}
\hline Soil property & Analysis result \\
\hline $\mathrm{pH}, 1: 2.5$ & 6.7 \\
$\mathrm{ECx} 10^{6}$ & 156 \\
Lime $\left(\mathrm{CaCO}_{3}\right), \%$ & 6.2 \\
Organic matter, \% & 1.1 \\
$\mathrm{Ca}, \%$ & 0.7 \\
$\mathrm{P}_{2} \mathrm{O}_{5}, \mathrm{~kg} \mathrm{da}^{-1}$ & 12.1 \\
$\mathrm{~K}_{2} \mathrm{O}, \mathrm{kg} \mathrm{da}^{-1}$ & 63.4 \\
$\mathrm{Mg}, \mathrm{mg} \mathrm{kg}^{-1}$ & 320.6 \\
$\mathrm{Fe}, \mathrm{mg} \mathrm{kg}^{-1}$ & 8.9 \\
$\mathrm{Cu}, \mathrm{mg} \mathrm{kg}^{-1}$ & 1.4 \\
$\mathrm{Zn}, \mathrm{mg} \mathrm{kg}^{-1}$ & 0.8 \\
$\mathrm{Mn}, \mathrm{mg} \mathrm{kg}^{-1}$ & 10.7 \\
\hline
\end{tabular}

According to Table 2, the experiment soil is identified as having neutral reaction, no salt, medium lime, organic matter insufficiency, medium phosphorus content, and $\mathrm{Mg}, \mathrm{Fe}, \mathrm{Cu}, \mathrm{Zn}$ and $\mathrm{Mn}$ content sufficiency.

Table 3. The mean of some climate data in cold greenhouse during the months of the research.

\begin{tabular}{lllll}
\hline Months & $\begin{array}{l}\text { Mean temperature } \\
\left({ }^{\circ} \mathrm{C}\right)\end{array}$ & $\begin{array}{l}\text { Max. temperature } \\
\left({ }^{\circ} \mathrm{C}\right)\end{array}$ & $\begin{array}{l}\text { Min. } \\
\text { temperature } \\
\left({ }^{0} \mathrm{C}\right)\end{array}$ & $\begin{array}{l}\text { Mean } \\
\text { humidity } \\
(\%)\end{array}$ \\
\hline October & 16.01 & 19.02 & 13.05 & 89 \\
November & 12.40 & 14.80 & 10.00 & 87 \\
December & 9.40 & 12.50 & 6.40 & 88 \\
\hline
\end{tabular}

The harvested plants were brought to the laboratory immediately; plants were washed with distilled water as two times; they were dried in a $68^{\circ} \mathrm{C}$ drying-oven until their weight got stabilized, and they were ground and prepared for the analysis. Then, nitrogen content of the samples was determined by the Kjeldahl method, and $\mathrm{P}, \mathrm{K}, \mathrm{Ca}, \mathrm{Mg}, \mathrm{S}, \mathrm{Fe}, \mathrm{Cu}, \mathrm{Zn}$ and $\mathrm{Mn}$ were determined by ICP Optical Emission Spectrometry (ICP-OES) (Kacar and Inal, 2010).

The experiment analysis results were evaluated applying SPSS 21 statistical program. ANOVA variance analysis was done on the research results and Duncan multiple comparison tests was done on this research results. 


\section{Results and Discussion \\ The Effect of Increasing Doses Leonardite Application on Some Macro Nutrient Elements Contents of Pak Choi.}

The effects of the increasing doses leonardite application on some macro nutrient elements contents of the pak choi were presented in the table 4 below.

Table 4. The effect of leonardite application on some macro nutrient element (N, P, K, Ca, Mg, S) contents of pak choi, \%, *,**

\begin{tabular}{lllllll}
\hline Doses*** & $\mathrm{N}$ & $\mathrm{P}$ & $\mathrm{K}$ & $\mathrm{Ca}$ & $\mathrm{Mg}$ & $\mathrm{S}$ \\
\hline $\mathrm{I}$ & $5.43 \mathbf{c}$ & $0.40 \mathbf{n s}$ & $5.49 \mathbf{c}$ & $1.85 \mathbf{c}$ & $0.12 \mathbf{n s}$ & $3.39 \mathbf{c}$ \\
II & $5.58 \mathbf{b}$ & $0.42 \mathbf{n s}$ & $5.73 \mathbf{b}$ & $1.91 \mathbf{c}$ & $0.13 \mathbf{n s}$ & $4.65 \mathbf{b}$ \\
III & $5.69 \mathbf{a}$ & $0.41 \mathbf{n s}$ & $5.83 \mathbf{b}$ & $2.06 \mathbf{b}$ & $0.13 \mathbf{n s}$ & $4.83 \mathbf{a}$ \\
IV & $5.73 \mathbf{a}$ & $0.41 \mathbf{n s}$ & $6.01 \mathbf{a}$ & $2.29 \mathbf{a}$ & $0.14 \mathbf{n s}$ & $4.84 \mathbf{a}$ \\
\hline
\end{tabular}

*: The values mean of three replications, **: each element was evaluated individually and values in the same column with different letters are statistically significant at the level of $5 \%$, ns: non-significant, ***: (I: 0 ppm m², II: 60 ppm m², III: 120 ppm $\mathrm{m}^{-2}$, and IV: $150 \mathrm{ppm} \mathrm{m}^{-2}$ ).

According to Table 4, the total $\mathrm{N}$ content of the plant samples were determined of $5.43 \%, 5.58 \%, 5.69$ $\%$, and $5.73 \%$ for four leonardite doses respectively. The contents were determined as $\mathrm{P}(0.40 \%, 0.42$ $\%, 0.41 \%, 0.41 \%)$; K (5.49\%, $5.73 \%, 5.83 \%, 6.01 \%)$; Ca $(1.85 \%, 1.91 \%, 2.06 \%, 2.29 \%) ; \mathrm{Mg}$ $(0.12 \%, 0.13 \%, 0.13 \%, 0.14 \%)$; and S $(3.39 \%, 4.65 \%, 4.83 \%, 4.84 \%)$ for four doses, respectively. According to the results, the effects of the increasing doses of the leonardite practice on some macro nutrient elements contents of pak choi were determined statistically significant. These increases were found to be significant at the level of $5 \%$ statistical degree, except $\mathrm{P}$ and $\mathrm{Mg}$ nutrient elements.

According to Chen and Aviad, 1990 influences of humic acid having fertilizers on nutrient uptake addict to humic acid resource such as leonardite, concentration, practice type, plant species and cultivars.

According to David et al., 1994 leonardite attend to increase available N, and diverse plant nutrients, such as $\mathrm{K}$.

According to Fernandez et al., 1996 foliar application of leonardite to young olive plants stimulated shoot growth while they were growing without the supplement of mineral elements to the irrigation water. Foliar application of leonardite extracts stimulated shoot growth and supported the concentration of $\mathrm{K}, \mathrm{Ca}$ in leaves.

According to Chen and Aviad, 1990; Nardi, et al., 2002; Escobar, et al., 1996 leonardite may have direct and indirect effects on the plant growth. Direct effects are those, which require uptake of humic matters into the plant tissue resulting in diverse biochemical effects.

Many researchers from various regions who work on various plants also revealed that the increasing doses of the leonardite application cause a significant rise in the $\mathrm{N}, \mathrm{P}, \mathrm{K}, \mathrm{Ca}, \mathrm{Mg}, \mathrm{S}$ content of the plants (Topcuoglu and Onal, 2006; Saglam et al., 2012; Turan et al., 2012; Kucukyumuk et al., 2014). And these results are similar to our research.

\section{The Effect of Increasing Doses Leonardite Application on Some Micro Nutrient Element Contents of Pak Choi.}

The effects of increasing doses leonardite application on some micro nutrient element content of pak choi are presented in the Table 5 below. 
Table 5. The effect of leonardite application on some micro nutrient element contents of pak choi, $\mathrm{mg} \mathrm{kg}^{-1}, *, * *$

\begin{tabular}{lllll}
\hline Doses*** & $\mathrm{Fe}$ & $\mathrm{Cu}$ & $\mathrm{Zn}$ & $\mathrm{Mn}$ \\
\hline I & $96.63 \mathbf{c}$ & $5.08 \mathbf{c}$ & $32.87 \mathbf{c}$ & $12.30 \mathbf{d}$ \\
II & $110.60 \mathbf{b}$ & $8.98 \mathbf{c}$ & $34.43 \mathbf{b}$ & $16.70 \mathbf{c}$ \\
III & $112.37 \mathbf{b}$ & $18.92 \mathbf{b}$ & $36.37 \mathbf{a}$ & $22.93 \mathbf{b}$ \\
IV & $120.94 \mathbf{a}$ & $24.38 \mathbf{a}$ & $37.73 \mathbf{a}$ & $94.87 \mathbf{a}$ \\
\hline
\end{tabular}

*: The values mean of three replications, **: each element was evaluated individually and values in the same column with different letters are statistically significant at the level of $5 \%$, ns: non-significant, ***: (I: 0 ppm m² ${ }^{-2}$ II: 60 ppm m ${ }^{-2}$, III: 120 ppm $\mathrm{m}^{-2}$, and IV: $150 \mathrm{ppm} \mathrm{m}^{-2}$ ).

According to Table 5, and some micro elements contents were obtained as Fe $\left(96,110,112,120 \mathrm{mgkg}^{-}\right.$ $\left.{ }^{1}\right) ; \mathrm{Cu}\left(5,8,18,24 \mathrm{mgkg}^{-1}\right)$; $\mathrm{Mn}\left(12,16,22,94 \mathrm{mgkg}^{-1}\right)$; and $\mathrm{Zn}\left(32,34,36,37 \mathrm{mgkg}^{-1}\right)$ for four doses, respectively. According to the results, the effects of the increasing doses of the leonardite practice on some micro nutrient elements ingredient of pak choi were determined statistically significant. These increases were found to be significant at the level of $5 \%$ statistical degree.

According to Fernandez et al., 1996 foliar application of leonardite to young olive plants stimulated shoot growth while they were growing without the supplement of mineral elements to the irrigation water. Foliar application of leonardite extracts stimulated shoot growth and supported the concentration of $\mathrm{Fe}$ in leaves.

In a research by Sozudogru et al. (1996), which was conducted by using bean plant, some similar results emerged with the research mentioned previously, where 5 different doses of humic acid $(0,30,60,90$ and $120 \mathrm{mg} \mathrm{kg}^{-1}$ ) were implemented to the plants. As a result, a significant increase was observed in the $\mathrm{Fe}, \mathrm{Zn}$ and $\mathrm{Mn}$ ingredient of the bean plant with the increasing doses of humic acid.

In an experiment carried out by using tomato plant under greenhouse conditions. It was proven that the leonardite applied to plants has positive effects on the amount of tomato fruit production. Furthermore, the $\mathrm{Fe}, \mathrm{Zn}$ and $\mathrm{Mn}$ nutrition content of plant leaves increases with the leonardite application (Topcuoglu and Onal, 2006).

The research by Turan et al., 2012 the results show that the humic acid applied for the leaf increases the dry matter amount of the corn plant and the amounts of $\mathrm{Cu}$ and $\mathrm{Zn}$, which are taken from the soil by the plant.

In a greenhouse experiment carried out by Gunaydin (1999) with corn plant, some 0, 50, 100, 150, 200 and $250 \mathrm{mg} \mathrm{kg}^{-1}$ humic acid are applied to the plants. At the end of the experiment, significant increases were observed in the $\mathrm{Fe}, \mathrm{Cu}, \mathrm{Zn}$ and $\mathrm{Mn}$ ingredient of corn plant with the increasing doses of humic acid applications. These results are similar to our research.

\section{Conclusions}

The present research which aims to investigate the effects of the increasing doses of the leonardite application on the pak choi with regard to some macro and micro nutrient elements of the content, significant increases in the pak choi of the $\mathrm{N}, \mathrm{P}, \mathrm{K}, \mathrm{Ca}, \mathrm{Mg}, \mathrm{S}, \mathrm{Fe}, \mathrm{Cu}, \mathrm{Zn}$ and $\mathrm{Mn}$ nutrient elements were determined as compared to the control group. According to the experiment results, the increasing doses of the leonardite application provide the increasing in the pak choi of some macro and micro nutrient elements. These increases are important with a $5 \%$ statistical degree, except for $\mathrm{P}$ and $\mathrm{Mg}$ nutrient elements.

The organic fertilizers and soil improvers, such as the leonardite, are commonly used in agriculture in the recent years. As a consequence, the excessive and unconscious use of the chemical fertilizers in agriculture has caused serious problems in the quality of the agricultural products. Besides, much of the soil in Turkey has insufficient organic matter (Akca et al. 2003; Adiloglu et al., 2018; Belliturk, 2018; Adiloglu and Saglam, 2015; Adiloglu and Karaman, 2015). The use of organic materials in agriculture, 
such as leonardite, in eliminating the insufficiency of the organic matter content and in maintaining the productivity of soils, therefore, is highly needed.

\section{Acknowledgements}

The abstract of this paper has been presented at the national conference "Turkey Natural Nutrition and Healthy Living 2016".

\section{References}

Adiloglu, S. and Saglam, M.T. (2015). Organic Matter Content of Near the Highway Soils in Tekirdag Province. KSU Journal of Natural Sciences, 18 (3): $49-53$ (in Turkish).

Adiloglu, A. and Karaman, M.R. (2015). Changing Trendy of Organic Matter Content in Trakya Region Soils Between 1984 and 2013 years. KSU Journal of Natural Sciences, 18 (3): $44-48$ (in Turkish).

Adiloğlu, A., Bellitürk, K., Adiloğlu, S. and Solmaz, Y., 2018. The Effect of Increasing Leonardit Applications on Dry Matter Yield and Some Nutrient Elements Contents of Rye (Secale cerale L.) Plant. Eurasian Journal of Forest Science, 6 (1): 44-51.

Akca, L., Ayaz, S.C., Tuncsiper, B., Yinanc, A., Bayhan, H., Ceyhan, M., (2003). Scientrific Basis of Nonpoint Source Pollution Control in Reservoir Catchments by Constrveted Wetland System. Science of the Total Environment, 3: 25-34.

Akinremi, O.O., R.L. Janzen, R.L. Lemke, F.J. Larney, (2000). Response of Canola, Wheat and Green Beans to Leonardite Additions. Canadian Journal of Soil Science, 80:437-443

Bellitürk, K., 2016. Vermicomposting Technology for Solid Waste Management in Sustainable Agricultural Production. Çukurova J. Agric. Food Sci. 31 (3): 1-5.

Bellitürk, K., 2018. Some Evaluations about Use of Vermicompost in Agricultural Activity of Thrace Region, Turkey: A Review. Journal of Rice Research, 6 (2): 1000193

Chen, Y. and Aviad, T. (1990). Effect of Humic Substances on Plant Growth. In: Humic Substances in Soil and Crop Sciences: Selected Readings, Ed., P. McCarthy, Am. Soc. of Agron., and Soil Sci. Soc. of Am., Madison, Wisconsin, 161-186 p.

Cimrin, K.M., Y1lmaz, I. (2005). Humic Acid Applications to Lettuce Do not Improve Yield but Do Improve Phosphorus Availability. Acta Agri. Scand., 55: 58-63.

David, P.P., Nelson, P.V., Sanders, D.C. (1994). Humic Acid Improves Growth of Tomato Seedling in Solution Culture. Journal of Plant Nutrition, 17: 173-184.

Dixon, G.R. (2007). Vegetable Brassicas and Related Crucifers. CAB International North American Office, 875 Massachusetts Avenue, 7th Floor, Cambridge, MA 02139 USA. 327 p.

Dursun, A., Guvenc, I., Turan, M., (2002). Effects of Different Levels of Humic Acid on Seedling Growth and Macro and Micronutrient Contents of Tomato and Eggplant, Acta Agrobotanica. 56:81-88.

Ece, A., Saltali, K., Eryigit, N., and Uysal, F. (2007). The Effects of Leonardite Applications on Climbing Bean (Phaseolus vulgaris L.) Yield and the Some Soil Properties. Journal of Agronomy, 6: 480-483.

Eryilmaz Acikgoz, F. (2016). Seasonal Variations on Quality Parameters of Pak Choi (Brassica rapa L. subsp. chinensis L.). Advances in Crop Science and Technology, 4: 4, 1000233. DOI: 10.4172/2329-8863.1000233.

Escobar, R.F., Benlloch, M., Barranco, D., Duenas A., and Ganan, J.A.G. (1996). Response of Olive Trees to Foliar Application of Humic Substances Extracted from Leonardite. Scientia, 66: 191-200. 
Fernandez, R.E., Benlock, M,. Barranco, D., Duenas A. and Ganan, J.A.G. (1996). Response of Olive Trees to Foliar Application of Humic Substances Extracted from Leonardite. Scientia Horticulturae, 66: 191-200.

Gunaydin, M. (1999). The Effects of Foliar and Soil Humic Acid Application on Growing and Some Nutrient Element Contents of Tomato and Maize. Ankara Univ. Graduate School of Natural and Applied Sci., MSc. Thesis, Ankara (in Turkish).

Hanelt, P. (1986). Formal and Informal Classifications of the Infraspecific Variability of Cultivated Plantsadvantages and Limitations. In: Styles, B.T. (ed.), Intraspecific Classification of Wild and Cultivated Plants, pp. 139-156. Oxford.

Kacar, B. and Inal, A. (2010). Plant Analysis. Nobel Yayinlari, No: 849, Ankara (in Turkish).

Kucukyumuk, Z., Demirekin, H., Almaz, M. and Erdal, I. (2014). Effects of Leonardite and Mycorrhiza on Plant Growth and Mineral Nutrition in Pepper Plant. Suleyman Demirel University Journal of Agricultural Faculty, 9 (2): 42-48 (in Turkish).

Larkcom, J. (2007). Oriental Vegetables. Frances Lincoln Ltd., London, UK.

Makino, T. (1912). Observations on the Flora of Japan. Botanical Magazine of Tokyo. 23: 93102.

Nardi, S., Pizzeghello D., Muscolo A. and Vianello, A. (2002). Physiological effects of humic substances on higher plants. Soil Biology and Biochemistry, 34: 1527-1536.

Opena, R.T., Kuo, C.G. and Yoon, J.Y. (1988). Breeding and Seed Production of Chinese Cabbage in the Tropics and Subtropics. AVRDC, Shanhua, Tairan, Tech Bull., 17: 92-95.

Saglam, M.T, Ozel, E.Z. and Belliturk, K. (2012). The Effect of Two Textured Soil with the Leonardite Organic Material on the Nitrogen Uptaking of Corn Plant. SAU Journal of Arts and Science, 14 (1): 383- 391.

Serenella, N., D. Pizzeghelloa, A. Muscolob, A. Vianello, (2002). Physiological Effects of Humic Substances on Higher Plants. Soil Biol. Biochem., 34:1527-1536.

Sozudogru, S., Kutuk, A.C., Yalcin, R. and Usta, S. (1996). The Effect of Humic Acid Application on Growing and Uptake of Nutrient Elements of Bean. Ankara Univ. Agricultural Faculty Publ., No: 1452 (in Turkish).

Tan, K.H., (2003). Humic Matter in Soil and Environment, Principles and Controversies, Marcel Dekker, Inc. 270 Madison Avenue, New York.

Tirasoglu, E., Cevik, U., Ertugrul, B., Apaydin, G., Baltas, H. and Ertugrul, M. (2005). Determination of Trace Elements in Cole (Brassica oleraceae var. acephale) at Trabzon Region in Turkey. Journal of Quantitative, Spectroscopy, Radiative Transfer, 94: 181-187.

Topcuoglu, B. and Onal, M.K. (2006). The Effects of Leonardite Application on Yield, Quality and Mineral Contents of Tomato Plant in Greenhouse Conditions. III. Organic Farming Symposium, Yalova (in Turkish).

Turan, M.A., Asik, B.B., Helik, H. and Katkat, A.V. (2012). Effect of Foliar Applied Humic Acid on Growth and Some Nutrient Elements Uptake of Maize Plant Under Salinity Conditions. SAU Journal of Arts and Science, 14 (1): 529- 539 .

Unlu, H., Ozdamar Unlu H., Karakurt, Y. (2010). Influence of Humic Acid on the Antioxidant Compounds in Pepper Fruit. Journal of Food Agric. Environ., 8:434-438.

Submitted: 03.05.2018 Accepted: 15.07.2018 